\title{
Konsep “Merdeka Belajar" dalam Pandangan Filsafat Konstruktivisme
}

\author{
${ }^{1}$ M. Yusuf, ${ }^{2}$ Witrialail Arfiansyah \\ ${ }^{12}$ UIN Sunan Ampel Surabaya \\ Email: vusuf.much21@gmail.com
}

\begin{abstract}
This paper tries to understand the "Merdeka Belajar" policy program launched by the Ministry of Education and Culture of the Republic of Indonesia in the light of constructivism philosophy. Constructivism is a philosophi that assumes that knowledge is self-construction. Because the nature and learning outcomes are subjective, and depend on each individual, also uncertain, for one's constructivism entity and are more easily recognized by the term "Clutter Paradigm". There are parallels between what was proclaimed by Mas Minister Nadiem Makarim and the concept of education according to the philosophy of the concept of constructivism. Both of them emphasize the aspects of freedom, independence, and flexibility of educational institutions in understanding the competence of students. Learning arrangement with a chaotic approach so that students can be safe, comfortable, and easy to learn. Students as learning subjects -learner control play an important role in structuring the learning. The initiative of children as learners to learn -the willingness to learn- will die when faced with many rules that do not exist in the learning process. It takes freedom, reality, as well as positive attitudes and perceptions of learning as basic capital in the danger of learning initiatives that ultimately result in success in learning.
\end{abstract}

Keywords: Learning, Merdeka Belajar, Constructivism Philosophy

\section{Pendahuluan}

Setiap negara wajib menyelenggarakan pendidikan bagi warganya, termasuk negara berkembang seperti Indonesia. Selain itu, adanya pendidikan dimaksudkan untuk mengembangkan kompetensi diri bagi setiap individu yang hidup di suatu negara tersebut. ${ }^{1}$ Hal ini sejalan dengan tujuan pendidikan nasional yang dijelaskan dalam Undang-Undang -UU- Republik Indonesia -RI- nomor 20 tahun 2003 Bab II pasal 3 tentang Sistem Pendidikan Nasional ${ }^{2}$ bahwa;

Pendidikan nasional berfungsi mengembangkan kemampuan dan membentuk watak serta peradaban bangsa yang bermartabat dalam rangka mencerdaskan kehidupan bangsa, bertujuan untuk berkembangnya potensi peserta didik agar menjadi manusia yang beriman dan bertakwa kepada Tuhan Yang Maha Esa, berakhlak mulia, sehat, berilmu, cakap, kreatif, mandiri, dan menjadi warga negara yang demokratis serta bertanggungjawab.

Pendidikan yang berkualitas mencerminkan masyarakat yang maju dan berkebudayaan. Pendidikan sendiri menjadi mesin penggerak kebudayaan. Dalam pidato pengukuhan guru besarnya, Asep Saifuddin Chalim -seorang profesor dalam bidang sosiologi pada satuan kerja UIN Sunan Ampel Surabaya- menegaskan bahwa zaman akan berubah seiring dengan perkembangan pendidikan. Juga sebaliknya, pendidikan

${ }^{1}$ M.D. Mayangsari, "Motivasi Berprestasi Ditinjau dari Penerimaan Orang Tua”, Jurnal Ecopsy, dan Penelitian Psikologi, vol. 1, no. 1, 2013, 18-23.

2 Undang-Undang Republik Indonesia Nomor 20 Tahun 2003 Tentang Sistem Pendidikan Nasional, [online], tersedia di https://www.unpad.ac.id/wp-content/uploads/2012/10/UU20-2003Sisdiknas.pdf, diakses pada 26 Agustus 2020, pukul 11.00 WIB. 
harus disesuaikan dengan minat pasar dan kebutuhan zamannya. ${ }^{3}$ Pendidikan nantinya akan mampu menghasilkan suatu hal yang kreatif dan inovatif dalam menapaki perkembangan zaman. Ketika negara ingin menciptakan kehidupan yang lebih baik bagi seluruh rakyatnya, maka tidak ada kata lain selain mempersiapkan pendidikan yang terbaik untuk memenuhi cita-cita tersebut. ${ }^{4}$ Apalagi, Indonesia saat ini diuntungkan dengan bonus demografi, yang mana penduduk Indonesia banyak dengan jumlah usia produktif, yakni usia 15-64 tahun, sedangkan proporsi penduduk usia muda sudah semakin kecil dan proporsi penduduk usia lanjut belum begitu besar. ${ }^{5}$

Pemerintah Indonesia -sejak orde lama, orde baru, bahkan sampai saat ini, telah banyak memberikan perhatian dalam dunia pendidikan. Perhatian tersebut tercermin dalam setiap kebijakan yang dikeluarkan guna menuju pendidikan Indonesia yang lebih baik lagi. Taruhlah misal kebijakan program wajib belajar, beasiswa kepada masyarakat yang kurang mampu -sekarang dinamakan Bidik Misi, ada juga LPDP, serta menganggarkan 20 persen APBN untuk sektor pendidikan. ${ }^{6}$

Baru-baru ini $^{7}$, Mendikbud -Nadiem Anwar Makarim, yang kemudian akrab dipanggil Mas Menteri- mencanangkan kebijakan "Merdeka Belajar," yang mengundang banyak perhatian dari berbagai kalangan termasuk praktisi dan akademisi. Mereka mengkaji program ini sesuai dengan ketertarikan masing-masing. Mengingat, kebijakan

${ }^{3}$ Lihat selengkapnya dalam: Asep Saifuddin Chalim, Model Pendidikan dalam Mengatasi Problematika Masyarakat Masa Kini dan Akan Datang (Surabaya: UINSA Press, 2019).

4 Mencermati pidato Menteri Keuangan -Sri Mulyani Indrawati- yang menyatakan bahwa aset nasional selain benda ialah pendidikan rakyatnya, hal tersebut disampaikan dalam lounching beasiswa LPDP Khusus Santri. Lihat selengkapnya dalam Kementerian Keuangan Republik Indonesia, Media Keuangan Transparansi Informasi Kebijakan Fiskal, vol. 13, no. 135. 2018. [online]: tersedia di https://www.kemenkeu.go.id/media/11118/media-keuangan-desember-2018.pdf diakases pada 28 Agustus 2020.

${ }^{5}$ Bonus demografi di Indonesia dimulai dari tahun 2015-2035, dengan angka ketergantungan dependency ratio- dalam kisaran 0.4-0.5, yang artinya dalam setiap 100 orang usia produktif menanggung 4050 orang usia tidak produktif. Dan proporsi usia aak-anak kurang dari 15 tahun akan berkurang dibandingkan dengan usia kerja. Lihat dalam Nur Falikhah, Bonus Demografi Peluang dan Tantangan Bagi Indonesia, artikel pdf, [online] tersedia dalam https://www.researchgate.net/publication/331094049 BONUS DEMOGRAFI PELUANG DAN T ANTANGAN BAGI INDONESIA/link/5c656ac645851582c3e83267/download. diakses pada 28 Agustus 2020.

[online],

${ }^{6}$ Dewan Perwakilan Rakyat Repubil Indonesia, Anggaran Pendidikan dalam APBN, artikel pdf, http://www.dpr.go.id/doksetjen/dokumen/apbn_Anggaran_Pendidikan_dalam_APBN_2013013013570 8.pdf diakses pada 28 Agustus 2020. Juga dalam Kementerian Keuangan Republik Indonesia, Pokok-pokok APBN 2020 Akselerasi Daya Saing Melalui Inovasi dan Peguatan Kualitas Sumber Daya Manusia Mendukung Indonesia Maju (Jakarta: Kementerian Keuangan, 2020), 20. Pdf bisa didapatkan secara [online]: tersedia dalam https://www.kemenkeu.go.id/media/13730/informasi-apbn-2020.pdf diaskses pada 28 Agustus 2020 .

7 Penulis mengatakan "baru-baru ini" karena mengacu kepada kedua pemberitaan resmi yang diluncurkan oleh Kementerian Pendidikan dan Kebudayaan tentang Merdeka Belajar-Kampus Merdeka; pertama, mengenai aspek empat pokok kebijakan Merdeka Belajar, tertanggal 11 Desember 2019. Lihat selengkapnya dalam Biro Komunikasi dan Layanan Masyarakat, "Mendikbud Tetapkan Empat Pokok. Kebijakan Pendidikan "Merdeka Belajar," Kementerian Pendidikan dan Kebudayaan, 11 Desember 2019, [berita], https://www.kemdikbud.go.id/main/blog/2019/12/mendikbud-tetapkan-empat-pokokkebijakan-pendidikan-merdeka-belajar; kedua, mengenai empat kebijakan Merdeka Belajar: Kampus Merdeka, tertanggal 24 Januari 2020. Lihat selengkapnya di Biro Komunikasi dan Layanan Masyarakat, "Mendikbud Luncurkan Empat Kebijakan Merdeka Belajar: Kampus Merdeka," Kementerian Pendidikan dan Kebudayaan, 24 Januari 2020, [berita]: kemdikbud.go.id/main/blog/2020/01/mendikbud-luncurkanempat-kebijakan-merdeka-belajar-kampus-merdeka, diakses pada 30 Agustus 2020. 
"Merdeka Belajar" ini nantinya bersinggungan langsung dengan kehidupan dan kepentingan peserta didik. Oleh karena itu, menguak dan melacak kebijakan atau program "Merdeka Belajar" menjadi persoalan yang menarik untuk dikaji.

Dalam kaitannya dengan hal -"Merdeka Belajar"- tersebut, sekali lagi, memahami, menguak, melacak, dan mencoba memahami kebijakan tersebut dengan kacamata aliran filsafat konstruktivisme menarik untuk dikaji. Hal ini dikarenakan, Aliran filsafat konstruktivisme menghendaki agar siswa/anak didik menggunakan kemampuan yang dimilikinya untuk menyesuaikan diri dengan tuntutan perkembangan keilmuan dan zamannya. Anak didik harus aktif mengembangkan pengetahuan, bukan menerima umpan dan pengetahuan siap saji dari guru atau sesama siswa. Kreativitas dan keaktifan siswa menjadi prediktor utama dalam menjalani kehidupan siswa. Aliran ini mengutamakan peran siswa dalam berinisiatif. ${ }^{8}$

Akhirnya, dengan memahami dan menerapkan cara pandang aliran filsafat konstruktivisme dan dihubungkan dengan gebrakan kebijakan "Merdeka Belajar" yang sudah dicanangkan oleh Mas Menteri, nantinya diharapkan pendidikan di Indonesia mempunyai arah dan tujuan yang jelas. Juga, pendidikan di Indonesia semakin maju, berkualitas, dan sesuai dengan harapan semua rakyat Indonesia yang diamanatkan dalam UUD 1945.

\section{Pembahasan}

\section{A. Mengenal Filsafat Konstruktivisme}

Filsafat konstruktivisme merupakan filsafat pembelajaran yang populer di dekade ini. Konstruktivisme merupakan sebuah gerakan besar yang memiliki posisi filosofis dalam strategi dan pendekatan pembelajaran. Karena itu konstruktivisme sangat berpengaruh bagi dunia pendidikan. Namun, sebelum membahas filsafat konstruktivisme, alangkah baiknya membahas tentang filsafat pendidikan. Pertama, filsafat ialah studi tentang seluruh atau serangkaian fenomena kehidupan dan pemikiran manusia secara kritis dan dijabarkan dengan konsep mendasar.' Akhir dari pada filsafat ialah terjadinya dialektika, untuk itu filsafat tidak dialami dengan melakukan eksperimen atau percobaan, tapi dengan cara mengutarakan masalah secara persis, mencari solusinya, dan memberikan alasan yang logis untuk solusi tertentu. ${ }^{10}$

\footnotetext{
8 Waston, "Epistemologi Konstruktivisme dan Pengaruhnya terhadap Proses Belajar-Mengajar di Perguruan Tinggi", Subuf, vol. 26, no. 2, 2014, 121-130.

${ }^{9}$ Suaedi, Pengantar Filsafat Ilmu (Bogor: PT. Penerbit IPB Press, 2016), 17; Mukh Nursikin, "AliranAliran Filsafat Pendidikan dan Implementasinya dalam Pengembangan Kurikulum Pendidikan Islam”, Attarbiyah Journal of Islamic Culture and Education, vol. 1, no. 2, 2016, 303-334; lihat juga dalam Ismaun, Pengertian, Batasan Filsafat, Objek Material Filsafat, Objek. Formal Filsafat, dan Pemikiran Para Filsuf, Modul Pembelajaran, [online]: tersedia di http://repository.ut.ac.id/3922/1/PKNI4316-M1.pdf; juga dalam Anna Poedjiadi dan Suwarma Al Muchtar, Pengertian Filsafat, Modul Pembelajaran, [online]: tersedia di http://repository.ut.ac.id/4144/1/IDIK4006-M1.pdf. diakses pada 29 Agustus 2020.

${ }^{10}$ Lihat dalam Agustinus W. Dewantara, Logika Seni Berfikir Logis (Madiun: Wina Press, 2019), 13.
} 
Selanjutnya, filsafat pendidikan merupakan aplikasi dari filsafat dalam dunia pendidikan. ${ }^{11}$ Pendidikan membutuhkan filsafat karena masalah pendidikan tidak hanya menyangkut pelaksanaan pendidikan yang bisa diatasi dengan pengalaman, akan tetapi ada masalah yag lebih luas dan kompleks, yang tidak bisa dijabarkan atau dijangkau dengan fakta pendidikan, juga, tidak bisa dijangkau dengan sains pendidikan. $^{12}$

Istilah constructivism -yang dalam bahasa Indonesia diserap menjadi konstruktivisme- berasal dari kata kerja Inggris "to construct." Kata ini juga merupakan serapan dari bahasa Latin "conetruere" yang mempunyai arti menyusun atau membuat struktur. ${ }^{13}$ Secara istilah, konstruktivisme merupakan aliran filsafat yang menganggap bahwa pengetahuan adalah buah dari konstruksi -bentukan- diri sendiri. Lebih lanjut, Von Glasersfeld dalam Suparno menegaskan bahwa pengetahuan bukan suatu imitasi atau tiruan dari sebuah kenyataan. ${ }^{14}$ Pengetahuan tidak dapat ditransfer bagitu saja dari orang-orang tetapi harus diintepretasikan dalam diri sendiri oleh masing-masing diri. Pengetahuan bukan hasil instans, tapi proses yang berkembang terus menerus. ${ }^{15}$

Prinsip dasar filsafat konstruktivisme ialah bahwa semua pengetahuan dikonstruksikan -dibangun- dan bukan dipresepsi secara langsung oleh indra -baik penciuman, perabaan, pendengaran, penglihatan, dan seterusnya. Selanjutnya konstruktivisme berakar pada asumsi bahwa pengetahuan -tidak peduli bagaimana pengetahuan itu didefinisikan- terbentuk di dalam otak manusia, dan subyek yang berfikir tidak memiliki alternatif selain mengkonstruk pikirannya sendiri berdasarkan pengalaman yang telah dilalui. Semua pikiran tersebut berdasarkan pada diri sendiri, untuk itu ia bersifat subyektif. ${ }^{16}$ Akhirnya, pengetahuan yang dihasilkan dalam filsafat konstruktivisme ialah idiosyncratic, yaitu berdasarkan dari pemahaman dan pengalaman masing-masing. Pengetahuan juga bersifat dinamis dalam hakikatnya, karena manusia mengalami revisi konstruksi yang telah dibuat dan diperoleh, menggantinya dengan kognisi-kognisi baru seiring dengan bertambahnya pengalaman. ${ }^{17}$ Karena sifat dan hasil pembelajarannya subyektif, dan tergantung pada masing-masing individu, juga tidak menentu, untuk itulah filsafat konstruktivisme terkesan dan lebih mudah dikenali dengan istilah "Paradigma Kesemrawutan." Berbeda dengan pandangan behavioristik yang mengagungkan "keteraturan" dalam proses pembelajaran.

11 Amka, Filsafat Pendidikan (Sidoarjo: Nazamia Learning Center, 2019), 7; juga Dindin Ridwanudin, "Filsafat Pendidikan Sebagai Basis Penguatan Profesionalisme Guru", Jurnal Qathruna, vol. 2, no. 2, 2015.

12 Yunus Abu Bakar, Filsafat Pendidikan Islam (Surabaya: UINSA Press, 2014), 2.

${ }^{13}$ Sukiman, "Teori Pembelajaran dalam Pandangan Konstruktivisme dan Pendidikan Islam”, Jurnal Kependidikan Islam, vol. 3, no. 1, 2008. 59.

${ }_{14}$ Paul Suparno, Filsafat Konstruktivisme dalam Pendidikan (Yogyakarta: Kanisius, 2008), 28.

15 Nur Asiah, "Paradigma Kontemporer Sistem Pembelajaran Pendidikan Keguruan Madrasah Ibtidaiyah (PGMI)", Terampil Jurnal Pendidikan dan Pembelajaran Dasar, vol. 3, no. 2, 2016.

16 Amka, "Filsafat Pendidikan," 55.

17 Waston, "Epistemologi Konstruktivisme dan Pengaruhnya terhadap Proses Belajar-Mengajar di Perguruan Tinggi," 121-130. 
Tokoh-tokoh yang menggagas pendekatan konstruktivistik dalam pembelajaran ialah John Dewey, Maria Montessori, Jean Piaget, dan Lev Vigotsky. Piaget banyak menekankan konstruktivisme merupakan proses belajar dari sisi personal -Individual Cognitive Constructivist. Ia menjelaskan bagaimana proses pengetahuan seseorang dalam perkembangan intelektual. Pengetahuan merupakan adaptasi pikiran ke dalam suatu realitas. Istilah yang banyak digunakan Piaget dalam menjelaskan pengetahuan dikenal dengan istilah perkembangan kognitif, yaitu skema/skemata, asimilasi, akomodasi, dan equilibration. Sedangkan menurut Vigotsky pengetahuan menekankan dan membahas konstruktivisme proses belajar pada sisi sosial -Sociocultural Constructivist. Tidak ada teori konstruktivisme tunggal, namun setidaknya terdapat dua ide utama yang sama; pertama, pembelajar aktif secara biologi- dalam mengkonstruksikan pengetahuannya sendiri; kedua, interaksi sosial merupakan aspek penting dalam pengonstruksian pengetahuan. Sehingga perilaku seseorang muncul akibat dua elemen tersebut. ${ }^{18}$

\section{B. Pembelajaran dalam Pandangan Konstruktivisme}

Dulunya, orang beranggapan bahwa pembelajaran kelas ialah di mana siswa/peserta didik duduk manis; rajin membantu orang tua; taat dan patuh terhadap orang tua/guru; makan tidak boleh sambil bicara; belajar tidak boleh sambil bermain; penyeragaman pakaian sekolah; penyeragaman kurikulum; penyeragaman strategi pengajaran; penyeragaman bahan ajar; dan penyeragaman studi evaluasi. ${ }^{19}$ Beberapa hal ini karena bersumber dari penerapan "paradigma keteraturan" -behavioristik. Berdasarkan potret lapangan tersebut, penyelenggara pendidikan tidak sadar bahwa hal-hal di atas merupakan penyakit turunan yang belum dilakukan kajian keshahihannya. Bahkan, siapa saja yang ikut dalam pembelajaran -orang tua/guru- harus taat pada aturan tak tertulis di atas.

Cuplikan di atas sengaja penulis hadirkan sebagai pemantik komparatif pemahaman antara pembelajaran dalam pandangan/paradigma keteraturan behaviorisme- dan paradigma kesemrawutan -konstruktivisme;

\section{Pembelajaran dan Belajar}

Paradigma kesemrawutan -konstruktivisme, memandang bahwa pengetahuan merupakan suatu yang non-objective, bersifat temporer, berdasarkan pengalaman dan pengetahuan yang telah ada sebelumnya. ${ }^{20}$ Sedangkan behaviorisme memandang bahwa pengetahuan merupakan suatu yang objective, pasti, tidak berubah, dan tetap. ${ }^{21}$

${ }^{18}$ Euis Nurhidayati, "Pedagogi Konstruktivisme dalam Praksis Pendidikan Indonesia," Indonesian Journal of Educational Counseling, vol. 1, no. 1, 2017, 5.

19 Dadang Supardan, "Teori dan Praktik Pendekatan Konstruktivisme dalam Pembelajaran", Edunomic, vol. 4, no. 1, 2016.

20 Ahmad Nizar Rangkuti, "Konstruktivisme dan Pembelajaran Matematika," Jurnal Darul Ilmi, vol. 2, no. 2, 2014. 62 .

${ }^{21}$ Hikmah Uswatun Ummi dan Indrya Mulyaningsih, "Penerapan Teori Konstruktivistik pada Pembelajaran Bahasa Arab di IAIN Syekh Nurjati Cirebon”, Journal Indonesian Language Education and Literature, vol. 1, no. 2, 2016, 46. 
Belajar menurut teori behaviorisme merupakan perolehan pengetahuan, sedangkan mengajar ialah transfer pengetahuan ke orang yang belajar. Artinya, yang diajar harus memiliki pengetahuan sama dengan yang mengajar. Dan, apa yang dipahami oleh sang pengajar harus sama dengan yang dipahami oleh peserta didik. ${ }^{22}$ Sedangkan konstruktivisme menyatakan belajar ialah sebuah proses itu sendiri, penyusunan pengetahuan dari pengalaman konkrit, aktivitas kolaboratif, dan refleksi, serta intepretasi. Sedangkan mengajar adalah menata lingkungan agar sang pembelajar memiliki motivasi dalam menggali makna serta memaknai ketidakmenentuan. Karena inilah, sang pembelajar mengintepretasikan apa yang telah didapatkannya. ${ }^{23}$

Selanjutnya perihal fungsi mind -akal, behaviorisme memandang bahwa akal sebagai penjiplak struktur pengetahuan seperti yang ditentukan oleh struktur pengetahuan. ${ }^{24}$ Sedangkan konstruktivisme menerangkan bahwa akal sebagai alat untuk mengintepretasikan peristiwa, obyek, dan prespektif pada dunia nyata sehingga menghasilkan makna yang unik dan bersifat individualistik. ${ }^{25}$

Tabel 1: Pandangan behaviorisme dan konstruktivisme tentang pembelajaran/belajar

\begin{tabular}{|l|l|}
\hline \multicolumn{1}{|c|}{ Behaviorisme } & \multicolumn{1}{c|}{ Konstruktivisme } \\
\hline $\begin{array}{l}\text { Pengetahuan merupakan suatu yang objective, } \\
\text { pasti, tidak berubah, dan tetap. }\end{array}$ & $\begin{array}{l}\text { Pengetahuan merupakan suatu yang non- } \\
\text { objective, bersifat temporer, berdasarkan } \\
\text { pengalaman dan pengetahuan yang telah ada } \\
\text { sebelumnya }\end{array}$ \\
\hline $\begin{array}{l}\text { Belajar ialah perolehan pengetahuan, sedangkan } \\
\text { mengajar ialah transfer pengetahuan ke orang } \\
\text { yang belajar. }\end{array}$ & $\begin{array}{l}\text { menyatakan belajar ialah sebuah proses itu } \\
\text { sendiri, penyusunan pengetahuan dari } \\
\text { pengalaman konkrit, aktivitas kolaboratif, dan } \\
\text { refleksi, serta intepretasi. Sedangkan mengajar } \\
\text { adalah menata lingkungan agar sang } \\
\text { pembelajar memiliki motivasi dalam menggali } \\
\text { makna serta memaknai ketidakmenentuan. }\end{array}$ \\
\hline $\begin{array}{l}\text { Akal sebagai penjiplak struktur pengetahuan } \\
\text { seperti yang ditentukan oleh struktur } \\
\text { pengetahuan. }\end{array}$ & $\begin{array}{l}\text { akal sebagai alat untuk mengintepretasikan } \\
\text { peristiwa, obyek, dan prespektif pada dunia } \\
\text { nyata sehingga menghasilkan makna yang unik } \\
\text { dan bersifat individualistik. }\end{array}$ \\
\hline
\end{tabular}

\section{Lingkungan Belajar/Pembelajaran}

Karena behaviorisme memandang bahwa segala sesuatu di dunia ini terstruktur rapi, penuh dengan keteraturan, maka belajar harus ditetapkan terlebi dahulu aturan-aturan dan harus ditegakkan secara ketat. Pembiasaan dan disiplin menjadi hal wajib dan sangat esensial. Pembelajaran sama dengan tegaknya disiplin. Selanjutnya, kegagalan dan keterlambatan belajar sebagai sebuah kesalahan dan wajib dihukum. Dan, keberhasilan perlu diapresiasi dan biberi hadiah. ${ }^{26}$

22 Novi Irwan Nahar, "Penerapan Teori Belajar Behavioristik dalam Proses Pembelajaran", Nusantara (Jurnal Ilmu Pengetahuan Sosial), vol. 1, no. 1, 2016, 66.

${ }^{23}$ Hendri Purbo Waseso, "Kurikulum 2013 dalam Prespektif Teori Pembelajaran Konstruktivis", TA'LIM : Jurnal Studi Pendidikan Islam, vol. 1, no.1, 2018, 61-64.

${ }^{24}$ Novi Irwan Nahar, "Penerapan Teori Belajar Behavioristik dalam Proses Pembelajaran", 66.

25 Purbo Waseso, "Kurikulum 2013 dalam Prespektif Teori Pembelajaran Konstruktivis", 61-64.

${ }^{26}$ Jamridafriza, "Teori Belajar Behaviorisme dan Implikasinya dalam Praktek Pendidikan”, artikel pdf, [online]: https://www.researchgate.net/publication/289193100, 3. 
Sedangkan konstruktivisme jauh berbeda, belajar merupakan suatu kebebasan. Hanya dengan alam yang penuh kebebasan peserta didik dapat mengungkapkan makna yang diintepretasikan dari dunia nyata. Kebebasan menjadi hal wajib dan sangat esensial. Kegagalan atau keberhasilan merupakan suatu bentuk intepretasi yang wajib dihargai. Itulah sebabnya, penentu keberhasilan belajar ialah sebuah kebebasan. ${ }^{27}$

Tabel 2: Pandangan behaviorisme dan konstruktivisme tentang lingkungan pembelajaran/belajar

\begin{tabular}{|l|l|}
\hline \multicolumn{1}{|c|}{ Behaviorisme } & \multicolumn{1}{c|}{ Konstruktivisme } \\
\hline Kepastian, ketertiban, dan keteraturan. & $\begin{array}{l}\text { Kesemrawutan, ketidakpastian, dan } \\
\text { ketidakteraturan. }\end{array}$ \\
\hline Kontrol belajar dipegang pada selain pembelajar. & Kontol belajar dipegang pada si pembelajar. \\
\hline $\begin{array}{l}\text { Kegagalan dan ketidakmampuan memahami } \\
\text { pelajaran merupakan sebuah kesalahan dan wajib } \\
\text { mendapatkan hukuman. Begitupun sebaliknya, } \\
\text { keberhasilan dan kemampuan memahami } \\
\text { pelajaran merupakan sebuah prestasi dan wajib } \\
\text { mendapatkan pujian/hadiah. }\end{array}$ & $\begin{array}{l}\text { Kang betidakmampuan merupakan intepretasi } \\
\text { yajian/hadiah. }\end{array}$ \\
\hline $\begin{array}{l}\text { Ketaatan sebagai penentu keberhasilan, begitupun perlu mendapatkan } \\
\text { sebaliknya. Peserta didik hanya objek dari aturan. }\end{array}$ & $\begin{array}{l}\text { Kebebasan } \\
\text { keberhasilan. Peserta didik adalah subjek } \\
\text { yang mengendalikan lingkungan dan } \\
\text { mengontrol dirinya sendiri. }\end{array}$ \\
\hline
\end{tabular}

\section{E. Tujuan Pembelajaran}

Behaviorisme menekankan tujuan pembelajaran pada penambahan pengetahuan, sehingga belajar dilihat sebagai aktivitas "mimetic," yang menuntut mereka yang belajar mengungkapkan ulang dalam bentuk kuis, laporan, dan/atau tes. ${ }^{28}$ Sedangkan konstruktivisme menekankan pada belajar bagaimana belajar, terutama dalam menciptakan suatu pemahaman baru, yang menuntut perilaku/aktivitas kreatif-produktif dalam konteks nyata, yang mendorong peserta didik untuk berfikir ulang dan mendemonstrasikan apa yang sedang/sudah dipelajari. ${ }^{29}$

Tabel 3: Pandangan behaviorisme dan konstruktivisme tentang tujuan belajar

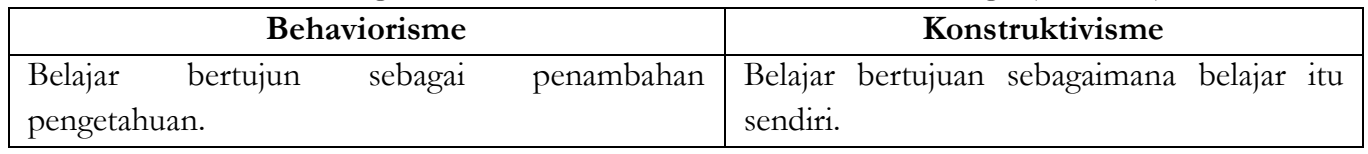

\section{F. Strategi Pembelajaran}

Strategi pembelajaran dalam pandangan behaviorisme lebih ke arah penyajian isi pada keterampilan yang terisolasi dan akumulasi fakta mengikuti aturan dan urutan dari sebagian atau seluruhnya. ${ }^{30}$ Sedangkan konstruktivisme menekankan pada penggunaan pengetahuan secara bermakna baik secara urutan keseluruhan atau sebagian. Oleh karenanya, behaviorisme menekankan pada penyelarasan dan mengikuti alur kurikulum dan ekspektasi akhir dari pembelajaran adalah hasil akhir

\footnotetext{
27 Purbo Waseso, "Kurikulum 2013 dalam Prespektif Teori Pembelajaran Konstruktivis" 61-64.

${ }^{28}$ Jamridafriza, "Teori Belajar Behaviorisme dan Implikasinya dalam Praktek Pendidikan", 3-4

${ }^{29}$ Purbo Waseso, "Kurikulum 2013 dalam Prespektif Teori Pembelajaran Konstruktivis" 61-64.

${ }^{30}$ Jamridafriza, "Teori Belajar Behaviorisme dan Implikasinya dalam Praktek Pendidikan”, 4.
} 
yang sesuai dengan isi buku teks. Namun, konstruktivisme menekankan pada meladeni pertanyaan atau pandangan si siswa. Maka, proses belajar lebih terkesan ke dalam proses analisis, membandingkan, generalisasi, memprediksi, dan menghipotesi. Itulah kiranya pembelajaran dalam konstruktivisme lebih ke arah proses. ${ }^{31}$

\begin{tabular}{|l|l|}
\hline \multicolumn{1}{|c|}{ Behaviorisme } & \multicolumn{1}{|c|}{ Konstruktivisme } \\
\hline $\begin{array}{l}\text { Pembelajaran mengikuti penyajian isi pada } \\
\text { keterampilan yang terisolasi dan akumulasi fakta } \\
\text { mengikuti aturan dan urutan dari sebagian atau } \\
\text { seluruhnya. }\end{array}$ & $\begin{array}{l}\text { konstruktivisme menekankan pada } \\
\text { penggunaan pengetahuan secara bermakna } \\
\text { baik secara urutan keseluruhan atau sebagian. }\end{array}$ \\
\hline Mengikuti kurikulum. & $\begin{array}{l}\text { Terlepas dari kurikulum, lebih banyak } \\
\text { meladeni pertanyaan dan pendapat siswa. }\end{array}$ \\
\hline Pembelajaran lebih mengikuti buku teks. & Menekankan pada proses berfikir kritis. \\
\hline Pembelajaran ditentukan oleh hasil akhir. & Pembelajaran ditentukan oleh proses. \\
\hline
\end{tabular}

\section{G. Evaluasi Pembelajaran}

Evaluasi dalam behaviorisme menekankan pada satu bentuk respon pasif, keterampilan terpisah, dan biasanya berupa paper test. Sedangkan evaluasi dalam konstruktivisme menekankan pada penyusunan pada makna secara aktif yang berintegrasi pada sebuah masalah dalam konteks nyata. Lebih lanjut evaluasi dalam behaviorisme lebih menuntut satu jawaban benar yang menunjukkan bahwa peserta didik sudah melakukan satu tugas belajar. ${ }^{32}$ Sedangkan konstruktivisme memunculkan pikiran untuk menjawab alasan, dan pemecahan masalah ganda. Berikutnya, evaluasi dalam behaviorisme merupakan sebuah bentuk terpisah dari pembelajaran, biasanya dilaksanakan setelah kegiatan belajar-mengajar di akhir semester dengan penekanan individual. Sedangkan konstruktivisme beranggapan bahwa evaluasi dilakukan sepanjang proses pembelajaran, yang menerapkan apa yang diajarkan pada konteks nyata. ${ }^{33}$

Tabel 5: Pandangan behaviorisme dan konstruktivisme tentang evaluasi pembelajaran

\begin{tabular}{|l|l|}
\hline \multicolumn{1}{|c|}{ Behavorisme } & \multicolumn{1}{|c|}{ Konstruktivisme } \\
\hline $\begin{array}{l}\text { Evaluasi pembelajaran biasanya dalam bentuk } \\
\text { respon pasif, keterampilan terpisah, dan } \\
\text { biasanya berupa paper test. }\end{array}$ & $\begin{array}{l}\text { Evaluasi pembelajaran biasanya menekankan } \\
\text { pada penyusunan pada makna secara aktif yang } \\
\text { berintegrasi pada sebuah masalah dalam konteks } \\
\text { nyata. }\end{array}$ \\
\hline $\begin{array}{l}\text { Evaluasi pembelajaran menuntut satu jawaban } \\
\text { benar yang menunjukkan bahwa peserta didik } \\
\text { sudah melakukan satu tugas belajar. }\end{array}$ & $\begin{array}{l}\text { Evaluasi pembelajaran biasanya memunculkan } \\
\text { pikiran untuk menjawab alasan, dan pemecahan } \\
\text { masalah ganda. }\end{array}$ \\
\hline $\begin{array}{l}\text { Evaluasi pembelajaran biasanya merupakan } \\
\text { sebuah bentuk terpisah dari pembelajaran, } \\
\text { biasanya dilaksanakan setelah kegiatan belajar- } \\
\text { mengajar di akhir semester dengan penekanan } \\
\text { individual. }\end{array}$ & $\begin{array}{l}\text { Evaluasi pembelajaran beranggapan bahwa } \\
\text { evaluasi dilakukan sepanjang proses } \\
\text { pembelajaran, yang menerapkan apa yang } \\
\text { diajarkan pada konteks nyata. }\end{array}$ \\
\hline
\end{tabular}

31 Purbo Waseso, "Kurikulum 2013 dalam Prespektif Teori Pembelajaran Konstruktivis", 61-64.

${ }^{32}$ Novi Irwan Nahar, "Penerapan Teori Belajar Behavioristik dalam Proses Pembelajaran", 68.

33 Purbo Waseso, "Kurikulum 2013 dalam Prespektif Teori Pembelajaran Konstruktivis”, 61-64. 


\section{H. “Kesemrawutan" dan Konsep “Merdeka Belajar”}

Merdeka belajar merupakan sebuah program yang dicanangkan oleh Mendikbud -Nadiem Anwar Makarim. Nadiem, lewat kementerian yang dinahkodainya membuat kebijakan ini bukan tanpa alasan. Pasalnya, menurut penelitian yang dilakukan oleh Programme for International Student Assesment -PISA- di tahun 2018, ia menyatakan bahwa posisi peserta didik Indonesia dalam bidang matematika dan literasi menempati posisi kedelapan dari bawah, yakni di urutan ke 70 dari 78 negara. ${ }^{34}$ Setelah itu, Nadiem membuat gebrakan penilaian dalam kemampuan minimum -meliputi literasi, numerisasi, dan survei karakter. Literasi dengan membahas kemampuan bernalar tentang dan menggunakan bahasa; numerisasi berisi tentang kemampuan bernalar menggunakan matematika; dan suvei karakter berisi tentang penerapan nilai-nilai agama, pekerti, dan Pancasila yang telah dipraktekkan oleh peserta didik. ${ }^{35}$

Lebih lanjut, Nadiem mengemukakan bahwa merdeka belajar ialah kemerdekaan berfikir. Guru menjadi kunci utama dalam kemerdekaan berfikir. ${ }^{36}$ Untuk itulah guru menjadi gerbang terdepan keberhasilan program baru Kemendikbud ini. Guru memiliki tugas yang mulia dan berat. Dalam sistem pendidikan nasional, guru ditugasi untuk mencerdaskan dan memajukan bangsa, namun guru banyak diberikan aturan daripada pertolongan. Kompetensi guru di level manapun, jika tidak ada penerjemahan dari Kompetensi Dasar-KD- dan kurikulum yang ada, tidak akan terjadi pembelajaran yang efektif.

Kedepannya, Mas Menteri mengharapkan agar pembelajaran tidak hanya terfokus dalam rombongan belajar -dalam kelas, melainkan juga mengadopsi sistem pelajaran luar kelas. Nuansa pelajaran akan lebih asyik dan enjoy, juga, tidak hanya terfokus pada mendengarkan penjelasan guru, nantinya peserta didik juga akan terbentuk karakter berani, mandiri, cerdik dalam bergaul, dan berkompetensi; tidak hanya mengandalkan sistem perangkingan kelas. ${ }^{37} \mathrm{Ada}$ empat point penting yang terdapat dalam kebijakan "Merdeka Belajar" Kemendikbud", yaitu;

1. Ujian Sekolah Berstandar Nasional -USBN- akan diganti dengan ujian -asesmenyang dilakukan dan diserahkan sepenuhnya kepada masing-masing sekolah.

34 Yohanes Enggar Harususilo, "Skor PISA 2018: Peringkat Lengkap Sains Siswa di 78 Negara," Kompas.com, Desember 07 2019, [Berita], https://edukasi.kompas.com/read/2019/12/07/10225401/skor-pisa-2018-peringkat-lengkap-sainssiswa-di-78-negara-ini-posisi, diakses pada 01 Sepember 2020.

35 Muhammad Yamin dan Syahrir, "Pembangunan Pendidikan Merdeka Belajar (Telaah Metode Pembelajaran)", Jurnal Ilmiah Mandala Education, vol. 6, no. 1, 2020; http://ejournal.mandalanursa.org/index.php/JIME/index

36 Yulius Obeta Pendi, "Merdeka Belajar yang Tercermin dalam Kompetensi Profesional Guru Bahasa Inggris SMP Negeri 01 Sedayu”, makalah disampaikan dalam Seminar Nasional Pendidikan "Implementasi Merdeka Belajar Berdasarkan Ajaran Tamansiswa" di Hotel Syahid Raya, 7 Maret 2020, vol. 1, no. $1,2020$.

${ }^{37}$ Lihat berita selengkapnya dalam ulasan yang disampaikan oleh R. Suyato Kusumaryono -Staf Bagian Hukum, Tata Laksana, dan Kepegawaian, Setditjen Guru dan Tenaga Kependidikan, Kemendikbud, "Merdeka Belajar," kemendikbud.go.id,18 Februari 2020, [artikel], https://gtk.kemdikbud.go.id/read-news/merdeka-belajar, diakses pada 01 September 2020.

${ }^{38}$ Kementerian Pendidikan dan Kebudayaan Republik Indonesia, Merdeka Belajar, (Kemendikbud, 11 Desember 2019). Juga lihat dalam Siti Mustaghfiroh, Konsep "Merdeka Belajar" Perspektif Aliran Progresivisme John Dewey, Jurnal Studi Guru dan Pembelajaran, vol. 3, no. 1, 2020. 146. 
Asesmen tersebut bisa dengan beberapa model; baik portofolio, penugasan, proyek kelompok, karya tulis, dan lain sebagainya, yang penting bersifat komperhensif. Akhirnya, guru lebih merdeka dalam menilai hasil belajar siswa.

2. Di tahun 2021 Ujian Nasional -UN- akan diganti dengan Asesmen Kompetensi Minimum dan Survei Karakter. Asesmen ini nantinya dilaksanakan pada kelas 4, 8, dan 11, bukan di akhir kelas. Karena nantinya hasil asesmen tersebut dibuat acuan peserta didik dalam perbaikan proses belajar sebelum menyelesaikan pendidikannya. Asesmen Kompetensi Minimum dan Survei Karakter tersebut meliputi literasi, numerisasi, dan survei karakter. Literasi, dengan membahas kemampuan bernalar tentang dan menggunakan bahasa; numerisasi berisi tentang kemampuan bernalar menggunakan matematika; dan suvei karakter berisi tentang penerapan nilai-nilai agama, pekerti, dan Pancasila yang telah dipraktekkan oleh peserta didik.

3. Penyederhanaan Rancangan Pelaksanaan Pendidikan -RPP, pengajar secara bebas dapat memilih, membuat, dan mengembangkan RPP. Hal terpenting dalam penyusunan RPP tersebut jika mencakup tiga hal, yakni tujuan pembelajaran, kegiatan pembelajaran, dan asesmen. RPP cukup dibuat satu halaman saja. melalui penyederhanaan tersebut diharapkan pengajar tidak terjerat dalam administrasi yang membutuhkan waktu lebih, dibanding dengan pengembangan kreatifitas dan kompetensi.

4. Membuat kebijakan Penerimaan Peserta Didik Baru-PPDB- lebih fleksibel -tidak termasuk daerah 3T. Jalur zonasi $50 \%$ dari yang sebelumnya $80 \%$; penambahan kuota jalur prestasi sebanyak 0-30\% -tergantung daerahnya- dari yang sebelumnya 15\%; penambahan jalur afirmasi $15 \%$ dari yang sebelumnya tidak ada jalur demikian; dan jalur perpindahan 5\%. Pemerintah daerah juga diberikan kewenangan secara teknis dalam menentukan daerah zonasi tersebut.

Akhirnya, merdeka belajar merupakan sebuah tawaran yang dalam merekonstruksi sistem pendidikan nasional. Perubahan zaman yang semakin dinamis harus kita sambut dengan penataan ulag sistem pendidikan. Dengan cara mengembalikan pendidikan pada hakikat yang semestinya, yakni memanusiakan manusia atau pendidikan yang membebaskan. Pengajar dan peserta didik saling melakukan mutual giving dan mutual understanding -saling memberikan manfaat dan saling memahami keinginan masing-masing. Pengajar bukan lagi sebagai sumber kebenaran mutlak, namun hanya sekedar fasilitator dalam proses pembelajaran dan penggerak dalam mencari kebenaran. Sudah tidak zamannya lagi pengajar melaksanakan indoktrinasi bagi semua peserta didiknya, namun keduanya -pengajar dan peserta didik- saling menggali kebenaran, daya nala yang kritism dan melihat dunia beserta fenomena yang dialegtis. Juga, mereformasi beban kerja pengajar di sekolah yang terlalu banyak disita oleh hal yang bersifat administratif. Oleh sebabnya kebebasan untuk berinovasi, belajar dengan mandiri, dan kreatif dapat dilakukan oleh penyelenggara pendidikan -pemangku kebijakan, pengajar, guru, siswa dan orangtua.

Dari pemaparan konsep "Merdeka Belajar" di atas, ada kesejajaran antara konsep yang dicanangkan oleh Mas Menteri Nadiem Makarim tersebut dengan konsep pendidikan menurut aliran filsafat konstruktivisme -kesemrawutan. 
Keduanya, sama-sama menekankan pada aspek kebebasan, kemerdekaan, dan keleluasaan lembaga pendidikan dalam eksplorasi secara maksimal kompetensi peserta didik. Jika kedua konsep -merdeka belajar dan filsafat pendidikan konstruktivisme- tersebut dirumuskan secara bersama-sama akan menghasilkan makna yang senada, yaitu; si pembelajar harus bebas dan berkembang secara natural; pembelajaran ialah berbasis pengalaman langsung; guru bukan sebagai giver, namun sebagai fasilitatior; pemangku lembaga sebagai penyedia laboratorium pendidikan untuk perubahan peserta didik; aktivitas di rumah dan di sekolah harus kooperatif. “Kebebasan” unsur penting dalam lingkungan belajar.

Penataan belajar dengan pendekatan kesemrawutan dimaksudkan agar peserta didik dapat aman, nyaman, dan mudah dalam belajar. Peserta didik sebagai subjek belajar -learner control, memegang peranan penting dalam penataan belajar tersebut. Karsa anak sebagai peserta didik untuk belajar -the will to learn- akan mati bila dihadapkan banyak aturan yang tidak ada hubungannya dengan proses belajar, sebagaimana yang telah dijelaskan dalam pembelajaran keteraturan di atas. Selain kebebasan, untuk memunculkan the will to learn ialah sikap realness-yakni kesadaran bahwa sang anak sebagai peserta didik mempunyai kekuatan dan kelemahan; keberanian dan juga rasa cemas; bisa marah juga bisa bergembira. ${ }^{39}$ Realness bukan hanya tergantung dan dimiliki oleh anak, tapi juga seluruh penyelenggara pendidikan -guru dan orang tua.

Lingkungan belajar yang bebas serta didasari oleh realness dari semua pihak yang terkait akan dapat menumbuhkan sikap dan presepsi yang positif terhadap belajar. ${ }^{40}$ Belajar akan dipandang sebagai sebuah pekerjaan yang menyenangkan dan menggembirakan. Oleh karena itu, pengajar seyogyanya membimbing anak mengembangkan sikap dan presepsi yang positif agar ia betah dan memperoleh kenikmatan dalam belajar. Seorang siswa yang merasa tidak nyaman dalam lingkungan belajar -kelas- umpamanya, ia tidak akan kerasan mengikuti proses pembelajaran.

Ketiga hal di atas -kebebasan, realness, serta sikap dan presepsi positif terhadap belajar- menjadi modal dasar dalam memunculkan karsa belajar. Tanpa sikap dan presepsi positif, pembelajaran tidak akan terjadi. Tanpa realness dari penyelenggara pendidikan -guru dan orang tua, tidak akan tercipta rasa aman. Juga, tanpa kebebasan, anak tidak akan belajar dengan caranya yang terbaik. Ketiga unsur itulah yang perlu ditonjolkan dalam penataan lingkungan belajar menurut paradigma "kesemrawutan". Dan, konsep "Merdeka Belajar" mencoba untuk mengarah kesana dengan kebijakan-kebijakan yang telah disebutkan di atas.

\footnotetext{
${ }^{39}$ Ni Nyoman Perni, "Penerapan Teori Belajar Humanistik dalam Pembelajaran", Adi Widya: Jurnal Pendidikan Dasar, vol. 3, no. 1, 2018.

40 Aina Mulyana, Soleh Hidayat, dan Sholih, "Hubungan antara Presepsi, Minat, dan Sikap Siswa dengan Hasil Belajar Siswa dalam Pembelajaran PKn", Jurnal Pendidikan dan Kebudayaan, vol. 19, no. 2, 2013.
} 
Bagan 1: Penataan alur lingkungan belajar

\begin{tabular}{|c|c|c|c|}
\hline $\begin{array}{c}\text { Kebebasan/ } \\
\text { kemerdekaan }\end{array}$ & Realness & $\begin{array}{l}\text { Sikap dan } \\
\text { presepsi positif } \\
\text { terhadap belajar }\end{array}$ & $\begin{array}{l}\text { Sukses } \\
\text { belajar }\end{array}$ \\
\hline
\end{tabular}

\section{Catatan Akhir}

Terakhir, sebagai kata penutup, penulis menegaskan bahwa sebagai paradigma "kesemrawutan," filsafat konstruktivisme merupakan kerangka pikir pemecahan masalah-masalah pembelajaran dengan merancang beragam tindakan belajar sesuai dengan keragaman kekhasan peserta didik, menuju tujuan yang beragam dengan strategi yang beragam, dan dengan melibatkan sumber-sumber yang beragam. Hal itu semua sesuai dengan konsep "Merdeka Belajar" yang digaungkan oleh Mas Menteri -Nadiem Anwar Makarim- mengenai kebebasan dalam belajar.

\section{Daftar Pustaka}

Amka, Filsafat Pendidikan. Sidoarjo: Nazamia Learning Center, 2019.

Asiah, Nur, "Paradigma Kontemporer Sistem Pembelajaran Pendidikan Keguruan Madrasah Ibtidaiyah (PGMI)", Terampil Jumal Pendidikan dan Pembelajaran Dasar, vol. 3, no. 2, 2016.

Bakar, Yunus Abu, Filsafat Pendidikan Islam. Surabaya: UINSA Press, 2014.

Biro Komunikasi dan Layanan Masyarakat, "Mendikbud Luncurkan Empat Kebijakan Merdeka Belajar: Kampus Merdeka," Kementerian Pendidikan dan Kebudayaan, 24 Januari 2020, [berita]: kemdikbud.go.id/main/blog/2020/01/mendikbudluncurkan-empat-kebijakan-merdeka-belajar-kampus-merdeka

Biro Komunikasi dan Layanan Masyarakat, "Mendikbud Tetapkan Empat Pokok Kebijakan Pendidikan "Merdeka Belajar," Kementerian Pendidikan dan Kebudayaan, 11 Desember 2019, [berita], https://www.kemdikbud.go.id/main/blog/2019/12/mendikbud-tetapkan-empatpokok-kebijakan-pendidikan-merdeka-belajar

Chalim, Asep Saifuddin, Model Pendidikan dalam Mengatasi Problematika Masyarakat Masa Kini dan Akan Datang. Surabaya: UINSA Press, 2019.

Dewan Perwakilan Rakyat Repubil Indonesia, Anggaran Pendidikan dalam APBN, artikel pdf, [online], tersedia dalam http://www.dpr.go.id/doksetjen/dokumen/apbn_Anggaran_Pendidikan_dalam_ APBN_20130130135708.pdf

Dewantara, Agustinus W., Logika Seni Berfikir Logis. Madiun: Wina Press, 2019.

Falikhah, Nur, Bonus Demografi Peluang dan Tantangan Bagi Indonesia, artikel pdf, [online] tersedia

dalam https://www.researchgate.net/publication/331094049 BONUS DEMOGRAFI PELUANG DAN TANTANGAN BAGI INDONESIA/link/5c656ac64585 1582c3e83267/download.

Harususilo, Yohanes Enggar, "Skor PISA 2018: Peringkat Lengkap Sains Siswa di 78 Negara," Kompas.com, 07 Desember 2019, [Berita], https://edukasi.kompas.com/read/2019/12/07/10225401/skor-pisa-2018peringkat-lengkap-sains-siswa-di-78-negara-ini-posisi.

Ismaun, Pengertian, Batasan Filsafat, Objek Material Filsafat, Objek Formal Filsafat, dan Pemikiran Para Filsuf, Modul Pembelajaran, [online]: tersedia di http://repository.ut.ac.id/3922/1/PKNI4316-M1.pdf; 
Jamridafriza, "Teori Belajar Behaviorisme dan Implikasinya dalam Praktek Pendidikan”, artikel pdf, [online]: https://www.researchgate.net/publication/289193100

Kementerian Keuangan Republik Indonesia, Media Keuangan Transparansi Informasi Kebijakan Fiskal, vol. 13, no. 135. 2018. [online]: tersedia di https://www.kemenkeu.go.id/media/11118/media-keuangan-desember-2018.pdf Kementerian Keuangan Republik Indonesia, Pokok-pokok. APBN 2020 Akselerasi Daya Saing Melalui Inovasi dan Peguatan Kualitas Sumber Daya Manusia Mendukung Indonesia Maju (Jakarta: Kementerian Keuangan, 2020), 20. Pdf bisa didapatkan secara [online]: tersedia dalam https://www.kemenkeu.go.id/media/13730/informasiapbn-2020.pdf

Kementerian Pendidikan dan Kebudayaan Republik Indonesia, Merdeka Belajar, Kemendikbud, 11 Desember 2019.

Kusumaryono, R. Suyato, -Staf Bagian Hukum, Tata Laksana, dan Kepegawaian, Setditjen Guru dan Tenaga Kependidikan, Kemendikbud, "Merdeka Belajar," kemendikbud.go.id,18 Februari 2020, [artikel], https://gtk.kemdikbud.go.id/readnews/merdeka-belajar

Mayangsari, D. "Motivasi Berprestasi Ditinjau dari Penerimaan Orang Tua", Jurnal Ecopsy, dan Penelitian Psikologi, vol. 1, no. 1, 2013.

Mulyana, Aina, Soleh Hidayat, dan Sholih, "Hubungan antara Presepsi, Minat, dan Sikap Siswa dengan Hasil Belajar Siswa dalam Pembelajaran PKn", Jurnal Pendidikan dan Kebudayaan, vol. 19, no. 2, 2013.

Mustaghfiroh, Siti, Konsep "Merdeka Belajar" Perspektif Aliran Progresivisme John Dewey, Jurnal Studi Guru dan Pembelajaran, vol. 3, no. 1, 2020.

Nahar, Novi Irwan, "Penerapan Teori Belajar Behavioristik dalam Proses Pembelajaran”, Nusantara (Jurnal Ilmu Pengetabuan Sosial), vol. 1, no. 1, 2016.

Nurhidayati, Euis, "Pedagogi Konstruktivisme dalam Praksis Pendidikan Indonesia," Indonesian Journal of Educational Counseling, vol. 1, no. 1, 2017.

Nursikin, Mukh, "Aliran-Aliran Filsafat Pendidikan dan Implementasinya dalam Pengembangan Kurikulum Pendidikan Islam”, Attarbiyah Journal of Islamic Culture and Education, vol. 1, no. 2, 2016.

Pendi, Yulius Obeta, "Merdeka Belajar yang Tercermin dalam Kompetensi Profesional Guru Bahasa Inggris SMP Negeri 01 Sedayu", makalah disampaikan dalam Seminar Nasional Pendidikan "Implementasi Merdeka Belajar Berdasarkan Ajaran Tamansiswa" di Hotel Syahid Raya, 7 Maret 2020, vol. 1, no. 1, 2020.

Perni, Ni Nyoman, "Penerapan Teori Belajar Humanistik dalam Pembelajaran", Adi Widya: Jurnal Pendidikean Dasar, vol. 3, no. 1, 2018.

Poedjiadi, Anna, dan Al Muchtar, Suwarma, Pengertian Filsafat, Modul Pembelajaran, [online]: tersedia di http://repository.ut.ac.id/4144/1/IDIK4006-M1.pdf.

Rangkuti, Ahmad Nizar, "Konstruktivisme dan Pembelajaran Matematika," Jurnal Darul Ilmi, vol. 2, no. 2, 2014.

Ridwanudin, Dindin, "Filsafat Pendidikan Sebagai Basis Penguatan Profesionalisme Guru", Jurnal Qathruna, vol. 2, no. 2, 2015.

Suaedi, Pengantar Filsafat Ilmu. Bogor: PT. Penerbit IPB Press, 2016.

Sukiman, "Teori Pembelajaran dalam Pandangan Konstruktivisme dan Pendidikan Islam", Jurnal Kependidikan Islam, vol. 3, no. 1, 2008.

Supardan, Dadang, "Teori dan Praktik Pendekatan Konstruktivisme dalam Pembelajaran”, Edunomic, vol. 4, no. 1, 2016.

Suparno, Paul Filsafat Konstruktivisme dalam Pendidikan. Yogyakarta: Kanisius, 2008. 
Ummi, Hikmah Uswatun dan Indrya Mulyaningsih, "Penerapan Teori Konstruktivistik pada Pembelajaran Bahasa Arab di IAIN Syekh Nurjati Cirebon", Journal Indonesian Language Education and Literature, vol. 1, no. 2, 2016.

Undang-Undang Republik Indonesia Nomor 20 Tahun 2003 Tentang Sistem Pendidikan Nasional, [online], tersedia di https://www.unpad.ac.id/wpcontent/uploads/2012/10/UU20-2003-Sisdiknas.pdf

Waseso, Hendri Purbo, "Kurikulum 2013 dalam Prespektif Teori Pembelajaran Konstruktivis", TA'LIM : Jumal Studi Pendidikan Islam, vol. 1, no.1, 2018.

Waston, "Epistemologi Konstruktivisme dan Pengaruhnya terhadap Proses BelajarMengajar di Perguruan Tinggi", Subuf, vol. 26, no. 2, 2014.

Yamin, Muhammad, dan Syahrir, "Pembangunan Pendidikan Merdeka Belajar (Telaah Metode Pembelajaran)", Jurnal Ilmiah Mandala Education, vol. 6, no. 1, 2020; http:// ejournal.mandalanursa.org/index.php/JIME/index 